\title{
Book Review \\ Joe Earle, Cahal Moran and Zach Ward-Perkins, The Econocracy: The Perils of Leaving Economics to the Experts, Manchester University Press, Pages: 240, 2017, Price: GBP 9.99 (LKR 2,129, Approx.), ISBN: 978-1-5261-1013-8 (pbk)
}

\author{
Harini Amarasuriya $a^{a}$ \\ ${ }^{a}$ Department of Social Studies, Open University of Sri Lanka, Sri Lanka
}

Suggested citation: Amarasuriya, H. (2018). [Review of the book The Econocracy: The perils of leaving economics to the experts by J. Earle, C. Moran \& Z. Ward-Perkins]. Colombo Business Journal. (9)1, 108-112

DOI: http://doi.org/10.4038/cbj.v9i1.24

(C) 2018 The Authors. This work is licenced under a Creative Commons Attribution 4.0 International Licence which permits unrestricted use, distribution, and reproduction in any medium, provided the original work is properly cited.

凶amarasuriyaharini9@gmail.com; (iD https://orcid.org/0000-0002-6647-110X

Econocracy: the perils of leaving economics to the experts, authored by a group of Economics students from the University of Manchester, provides a fascinating view of economics education, directly from the horse's mouth, so to speak. It's an extremely readable 212-page book organised into six chapters, with a foreword by Andrew Haldane, Chief Economist at the Bank of England. The simplicity of the style and tone makes the book very accessible to a wide audience. Written from the perspective of a generation that grew up around the 2008 global economic crisis, this book is a serious critique of the way in which a particular view of economics has taken over the way in which we define the world, and how generations of economists have been trained in recent times to uphold this view.

This book grew out of a movement among economics students in UK, who were increasingly frustrated with the education they were receiving. Despite the authority with which 'economics' was presented to them, they found that what they 
were learning did not help them understand what was actually happening in the world around them. This led them to initiate a campaign to reform economics education in early 2013. In the process, they discovered that there were students from other parts of the world, also engaged in similar campaigns, leading to a network of students called Rethinking Economics, over 40 groups from 13 different countries. Econocracy is the term they coined to describe a particular kind of political system that was dominant in the world: "An econocracy has all the formal institutions of a representative democracy - like political parties and regular elections - but the goals politics seeks to achieve are defined in narrow economic terms and decisions are made without significant public oversight" (p. 3). The book defines econocracy as "a society in which political goals are defined in terms of their effect on the economy, which is believed to be a distinct system with its own logic that requires experts to manage it" (p. 7).

Thus, the term econocracy refers to a political system in which politics has been reduced to economics or where the economy has become central to politics and policymaking. It also refers to the fact that economics has become a highly specialised technical field that is only understood by 'experts'. The authors argue that this high specialisation has made it impossible to engage in a democratic discussion on economics. Those who are trained as economists go on to hold important and authoritative positions in society, but speak a language that very few understand and yet influence and make decisions that significantly impact the public with very little oversight or restraint. They also argue that the education economists receive ill prepares them to understand or respond to the complex issues facing the world, effectively or responsibly. They point out that this state of affairs is a result of certain historical circumstances, including reforms to higher education which has placed severe financial pressures on the higher education sector, which seeks to compensate for funding cuts by increasing student numbers, cutting back on teaching staff and overemphasising research excellence as a marker of quality in higher education. This book is an attempt to understand these circumstances, the current situation of economics education and to offer ways of addressing the problems of economics education and its consequences.

One of the most important proposals put forward by the authors in this regard is the need for economics education to be democratised and to enable a public dialogue on economics rather than a closed debate among 'technical experts': "At Rethinking Economics our aims are to reform economics education so that 
tomorrow's experts are better equipped to understand the economy and engage with society. We are also trying to democratise economics because we believe that at its core economics should be a public discussion about how to organise society" (p. 5). The book argues that in the last several decades, economics has become more important than politics. Economics is no longer viewed as a political or social process: rather, the economy is seen as separate and de-linked from society and outside the sphere of democratic debate. This book examines the role of the discipline of economics in universities in this process.

The book describes in detail how economics got accepted as a neutral and scientific input into policy even though it- essentially out of the political domain. The authors argue that this technocratic view of economics, as being able to offer scientific and neutral input has become mainstream and accepted by politicians, the business community and the general public. Several examples are presented of how the technical language and tools of economics changes and redefines political problems, excluding important stakeholders from the decision making process. For example, the authors show how cost-benefit analysis (CBA), reduces hugely complex social problems into easily digestible figures and then assigns a monetary value. Such tools masks the fact that this type of analysis always involves choices, value judgments and assumptions that are inherently political in nature. For instance, concerns about equality, the environment, or women, cannot simply be reduced to a cost-benefit analysis. Yet, such tools and models are widely taught in economics courses around the world and then used in policy making processes, imbuing both economics and economists with huge power and influence, which lies largely outside the democratic process.

One of the most interesting parts of this book is the review of 174 economics modules offered in seven Russell Group universities ${ }^{1}$. The authors argue that despite economics being one of the most sought after academic programmes in the university system, the curricula (across the universities reviewed) is one sided with neo-classical economic theory dominating economics education. This version of economics education is based on highlighting models formulated on what the authors refer to as the "three prongs of neo-classical economics" (p. 38): individualism, optimization and equilibrium. Economics education does not discuss different schools of thoughts within economic theory and is far removed from the

${ }^{1}$ Cambridge, Cardiff, Exeter, London School of Economics, Manchester, Queen's University Belfast and Sheffield. 
real world. The assessment methods too, promote rote-learning and the uncritical application of theories and models with little reference to the complexities of the real world. In a shocking revelation, the authors state that their review of economics courses, showed that $76 \%$ of assessment questions required "no form of critical or independent thinking whatsoever" (p. 51) with many courses favouring multiplechoice questions, training students to find the 'one correct' answer for a problem, rather than to demonstrate the ability to critically evaluate several possible responses and provide a coherent argument in support of a particular conclusion.

The authors present a strong case for pluralism in economics based on two reasons: firstly, so that students may realise that there is more than one way to think about the economy, and secondly, in order to uphold widely held standards of academic practice which requires students to be trained to approach a problem from multiple perspectives, and to develop a critical and analytical perspective.

If there is one criticism I have of the book, it is the somewhat limited view of liberal democracy that the authors present. Liberal democracy is seen as the ideal political system for a society and econocracy is viewed as being incompatible with liberal democracy. Yet, we have plenty of examples in recent times of the limitations of liberal democracy. In fact, the individualism that is the corner-stone of neo-classical economic theory is very much part of the liberal democratic tradition as well. What is missing in the book is the analysis of the close relationship between liberal democracy and neo-classical economics. The kind of pluralism in economics that is advocated by the authors, requires a reimagining not just of economics but also of democracy. As argued by Mouffe (2005), there is an urgent need to look beyond liberal democracy to a more radical and plural democracy which can accommodate both the notion of the common good as well as that of individual desires and interests. This is a form of democracy that allows for the active political participation of people with different ideas of the conception of the good, but who are also bound by an identification with a set of common ethical and political values (Mouffe, 2005). Thus, while the authors rightly point to the indelible link between economics and politics, it is necessary to interrogate the kind of politics through which a more plural and just vision of the world is made possible. The fact that the generation that grew up through the global economic crisis and the resultant political fallout throughout the world is leading the campaign, bringing about reforms especially in education for such a change, is a cause for great optimism. 


\begin{abstract}
About the authors
Joe Earle, Cahal Moran and Zach Ward-Perkins are graduates from the University of Manchester and founding members of the Post-Crash Economics Society at the University of Manchester. They are also part of 'Rethinking Economics' in the UK, a movement that campaigns for pluralism in economics and to democratize economics.
\end{abstract}

\title{
References
}

Mouffe, C. (2005). The return of the political ( $1^{\text {st }}$ ed.). London: Verso 